\title{
Neotectonics of Kashaf Rud River, NE Iran by Modified Index of Active Tectonics (MIAT)
}

\author{
ElaheJavadi Mosavi, Mehran Arian* \\ Department of Geology, Science and Research Branch, Islamic Azad University, Tehran, Iran \\ Email: ${ }^{*}$ mehranarian@yahoo.com
}

Received 21 June 2015; accepted 25 July 2015; published 30 July 2015

Copyright (C) 2015 by authors and Scientific Research Publishing Inc.

This work is licensed under the Creative Commons Attribution International License (CC BY). http://creativecommons.org/licenses/by/4.0/

(c) ()

\begin{abstract}
Kashaf rud river is located in border zone of East Alborz and Kopet Dagh physiographic provinces in the north east Iran. Geomorphic indices are useful tools to show the neotectonic regimes. These indices have got the advantage of being calculated from Arc GIS and remote sensing packages over large area as a useful tool to identify geomorphic anomalies possibly related to active tectonics. In this research, seven geomorphic indices (stream-gradient index, valley floor width-valley height ratio, mountain-front sinuosity, drainage basin asymmetry, hypsometric integral, drainage basin shape and transverse topographic symmetry factor) were calculated along the Kashaf rud river. Then, based on a new index or modified index of active tectonics (Miat) values that calculated by average of seven geomorphic indices, relative tectonic activities levels were revealed. The low class of Miat is mainly in the sub-basins of No. 6, 10, 13, 14, 21, 22, 23, $24 \& 28$ while the rest of the study area has moderate tectonic activities in the other sub-basins. Our results show that the moderate value has located along faulted area, which shows 2 class of relative tectonic activity. These faults have been formed above an old suture zone between Cimmerian and Eurasian plates.
\end{abstract}

\section{Keywords}

Neotectonics, Miat, Geomorohic Index, Kashaf Rud, Iran

\section{Introduction}

The study area is around of Mashhad city in the border zone of East Alborz and Kopet Dagh physiographic provinces in the north east Iran (Figure 1). Dominant structural trend in East Alborz province is NW-SE in eastern part. From tectonics view, it contains Binalod magmatic arc and its fore arc basin with volcanic activities

\footnotetext{
*Corresponding author.
} 


\section{Physiographic-tectonic zoning map of Iran's sedimentary basins}

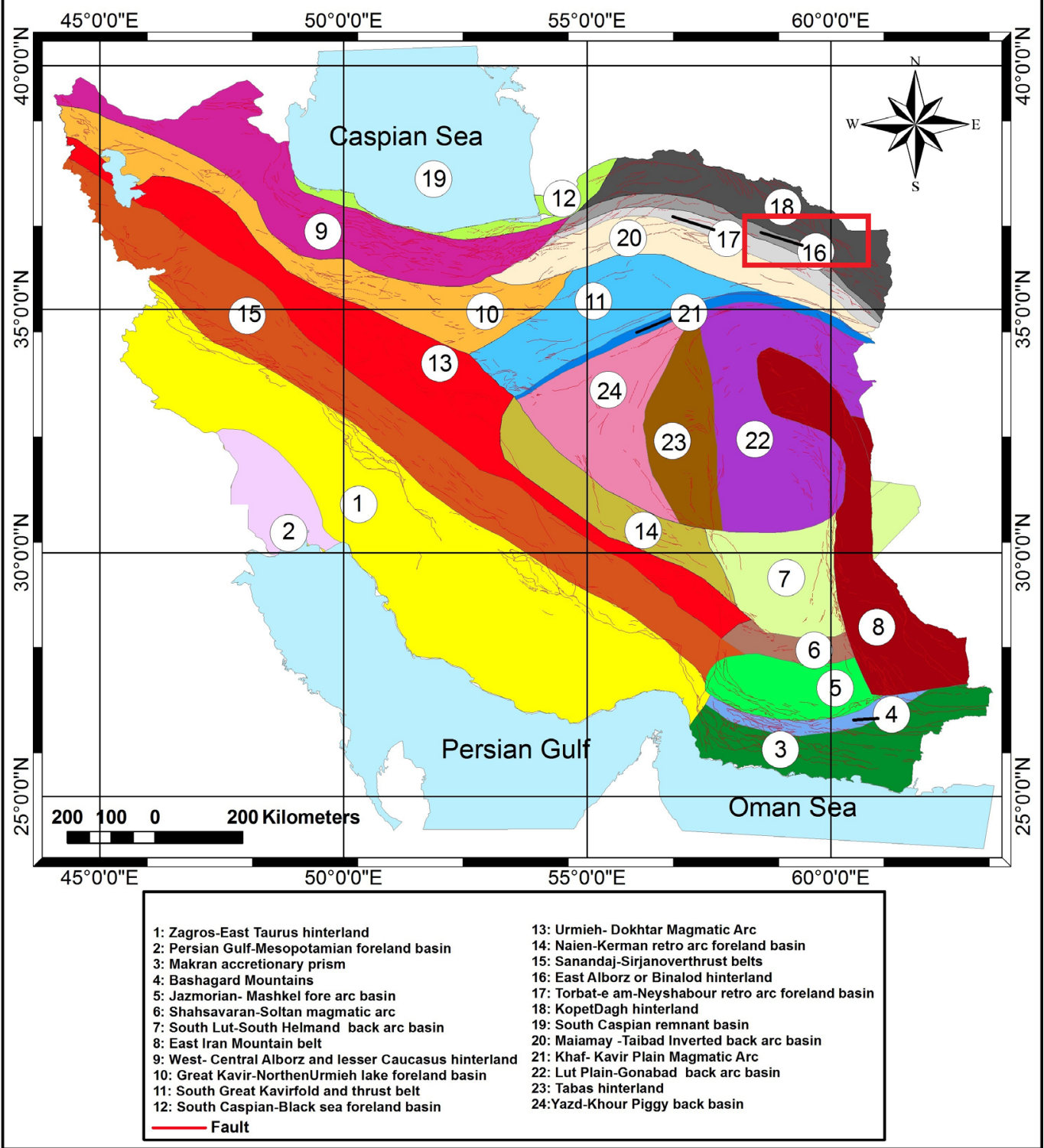

Figure 1. Physiographic-tectonic zoning map of Iran's sedimentary basins, modified from [1]. The study area is shown in the red rectangle.

(especially in Silurian) on northeastern of Cimmerian miniplate. Obduction of Mashhad ophiolite during late Paleozoic has been the result of subduction into beneath this province.

Dominant structural trend in Kopet Dagh province is NW-SE. From tectonics view, it contains the Kopet Dagh hinterland or Kopet Dagh fold and thrust belt that are formed in passive margin of Eurasian plate until late Triassic and then marine sedimentation on Kopet Dagh proforeland basin has continued to Eocene. Kopet Dagh hinterland has uplifted related to Karakorum foreland basin in northeast along Eshghabad fault [1]-[3]. In this research, area is divided into 28 sub-basins and the following indices are calculated: stream-gradient index ( $\mathrm{Sl}$ ), valley floor width-valley height ratio (Vf), mountain-front sinuosity (Smf), drainage basin asymmetry (Af), hypsometric integral (Hi), drainage basin shape (Bs) and transverse topographic symmetry factor (T). We use geomorphic indices of active tectonics, which are known to be useful for assessment of relative tectonic activities. Methodology for active tectonic studies [4]-[7] has been previously tested as a valuable tool in different 
tectonically active areas, namely SW USA [8] the Pacific coast of Costa Rica [9], Zagros, Iran [10], but in this research, we have used a new index as modified index of active tectonics (Miat) that calculated by average of seven geomorphic indices.

\section{Materials and Methods}

The calculated geomorphic indices are suitable for assessment of tectonic activity of the study area. The geomorphic indices such as: stream-gradient index (Sl), valley floor width-valley height ratio (Vf), mountain-front sinuosity (Smf), drainage basin asymmetry (Af), hypsometric integral (Hi), drainage basin shape (Bs) and transverse topographic symmetry factor $(\mathrm{T})$ are calculated in Kashaf rud river by using of topographic data and DEM (Figure 2 and Figure 3).

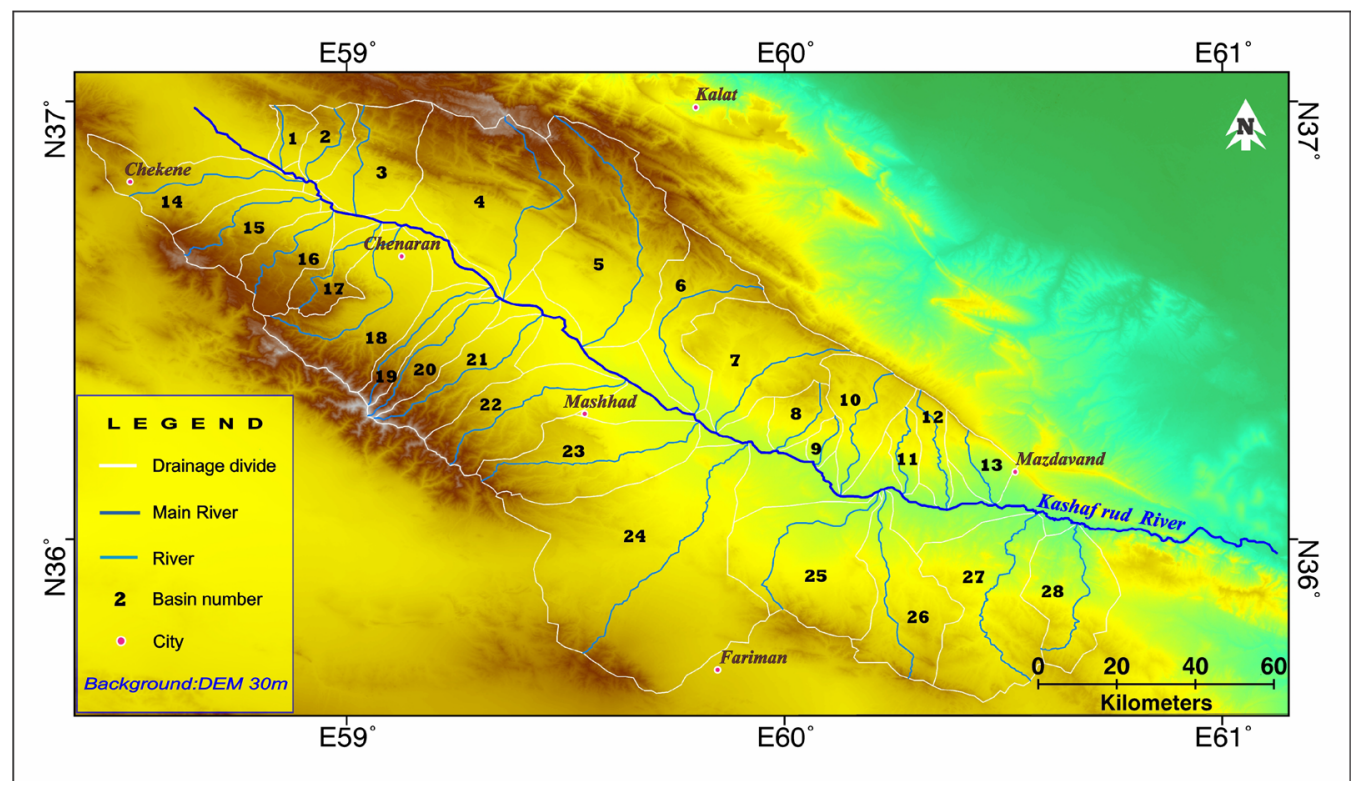

Figure 2. Digital Elevation model of the Kashaf rud river region.

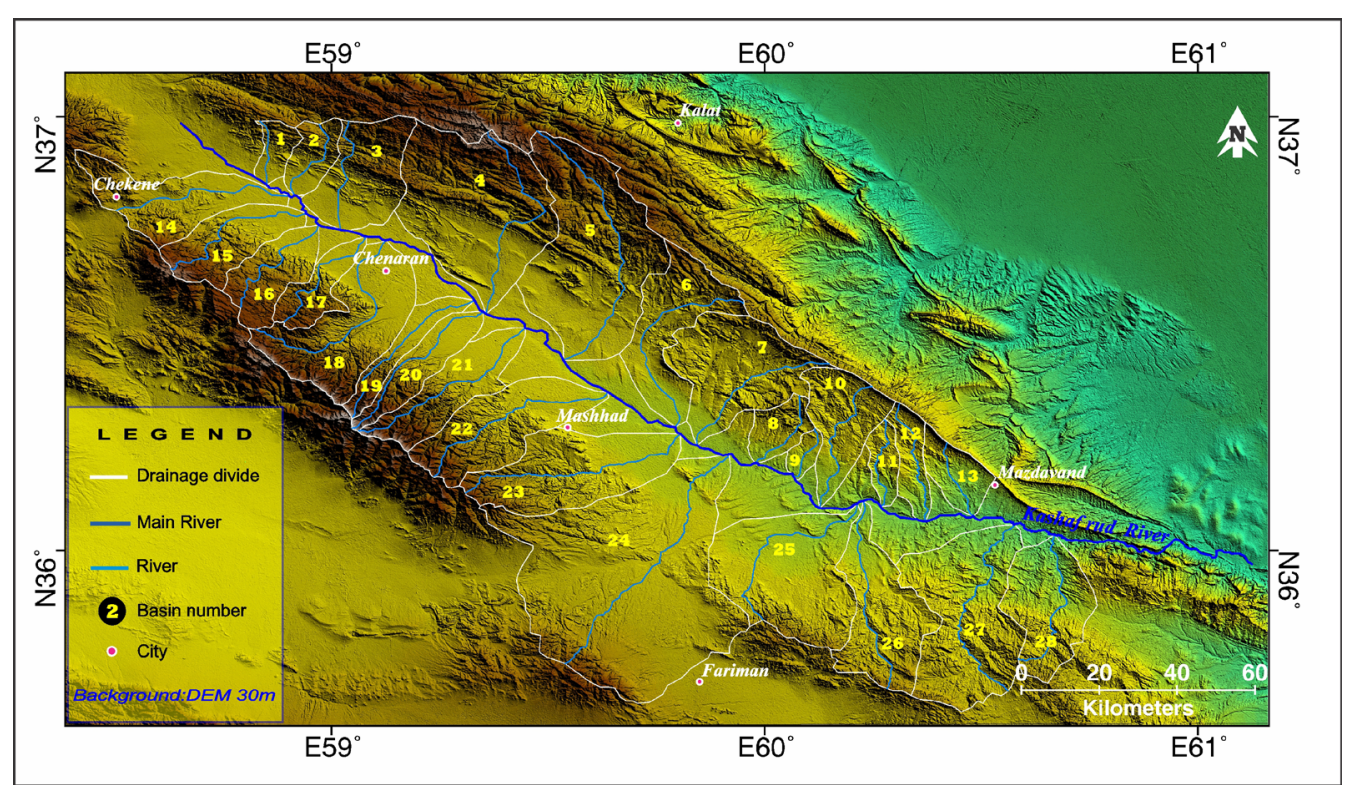

Figure 3. The relief of the Kashaf rud riverregion for identification of drainage pattern based on digital elevation model. 
On the other hand, the area was divided to 28 sub-basins, and for each one, above indices were calculated, then all of the indices were combined to obtain index of active tectonics (Iat) by new method [11]. Therefore, sub-basins can be compared together. The study area is located between longitudes E58, $30^{\prime}-61^{\circ}$ and latitudes $\mathrm{N} 35^{\circ}, 30^{\prime}-37^{\circ}$ in the Khorasan province, North East Iran. Based on previous work on the salt and mud diapirism [12]-[23] and neotectonic regime in Iran [24]-[29], Zagros in south Iran is the most active zone [30]-[47]. Then, Alborz [48]-[84] and Central Iran [85]-[100] have been situated in the next orders.

\section{Results and Discussion}

To study the indices, there is a formula which we turn to describe each one of indices. It is necessary to have some primary maps to calculate the indices, and the most important are: Digital Elevation Model (DEM), the drainage network and the sub-basins map of the Kashaf rud river that have been extracted from DEM (Figure 3). DEM extracted from a digitized topographic map (with 30 m intervals).

\subsection{The Stream-Gradient Index (SL)}

The rivers flowing over rocks and soils of various strengths tend to reach equilibrium with specific longitudinal profiles and hydraulic geometrics [101]-[103] defined the stream-gradient index (SL) to discuss influences of environmental variables on longitudinal stream profiles, and to test whether streams has reached equilibrium. The calculation formula is in this manner:

$$
\mathrm{SL}=(\Delta \mathrm{H} / \Delta \mathrm{L}) \mathrm{L}
$$

where $(\Delta \mathrm{H} / \Delta \mathrm{L})$ is local slope of the channel segment that is located between two contours and $\mathrm{L}$ is the channel length from the division to the midpoint of the channel reaches for which the index is calculated. This index is calculated along themaster streams of 28 sub-basins (Table 1). The SL index can be used to evaluate relative tectonic activity. An area on soft rocks with high SL values can be indicated for active tectonics. Based on our results, there are 2 and 3 classes (Figure 4).

\subsection{Valley Floor Width-Valley Height Ratio (Vf)}

Another index sensitive to tectonic uplift is the valley floor width to valley height ratio (Vf). This index can separate v-shaped valleys with small amounts from u-shaped valleys with greater amounts. The calculation formula is in this manner:

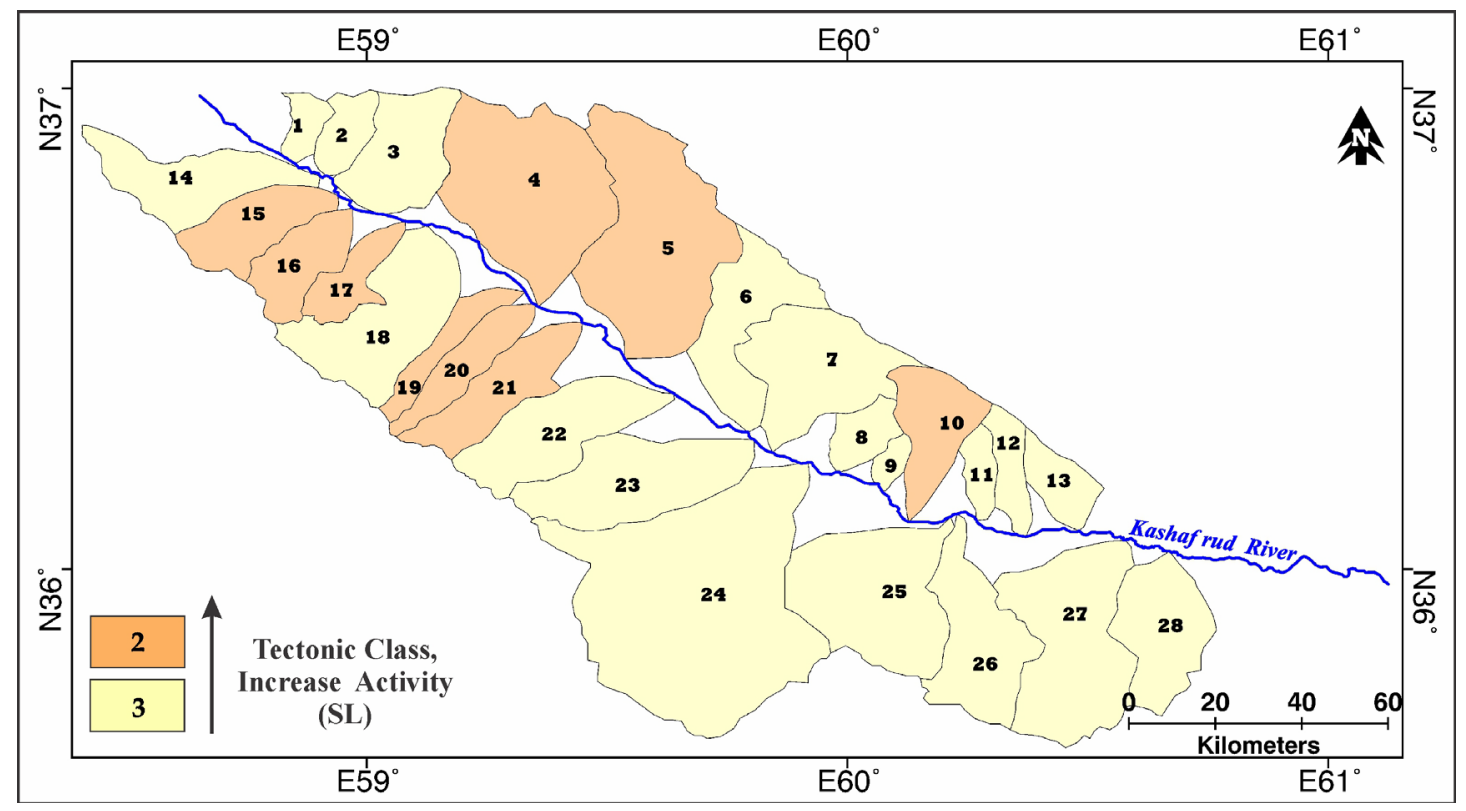

Figure 4. Classification of sub-basins based on stream length-gradient index. 
Table 1. Values of stream length-gradient index for sub-basins No.1 and 28.

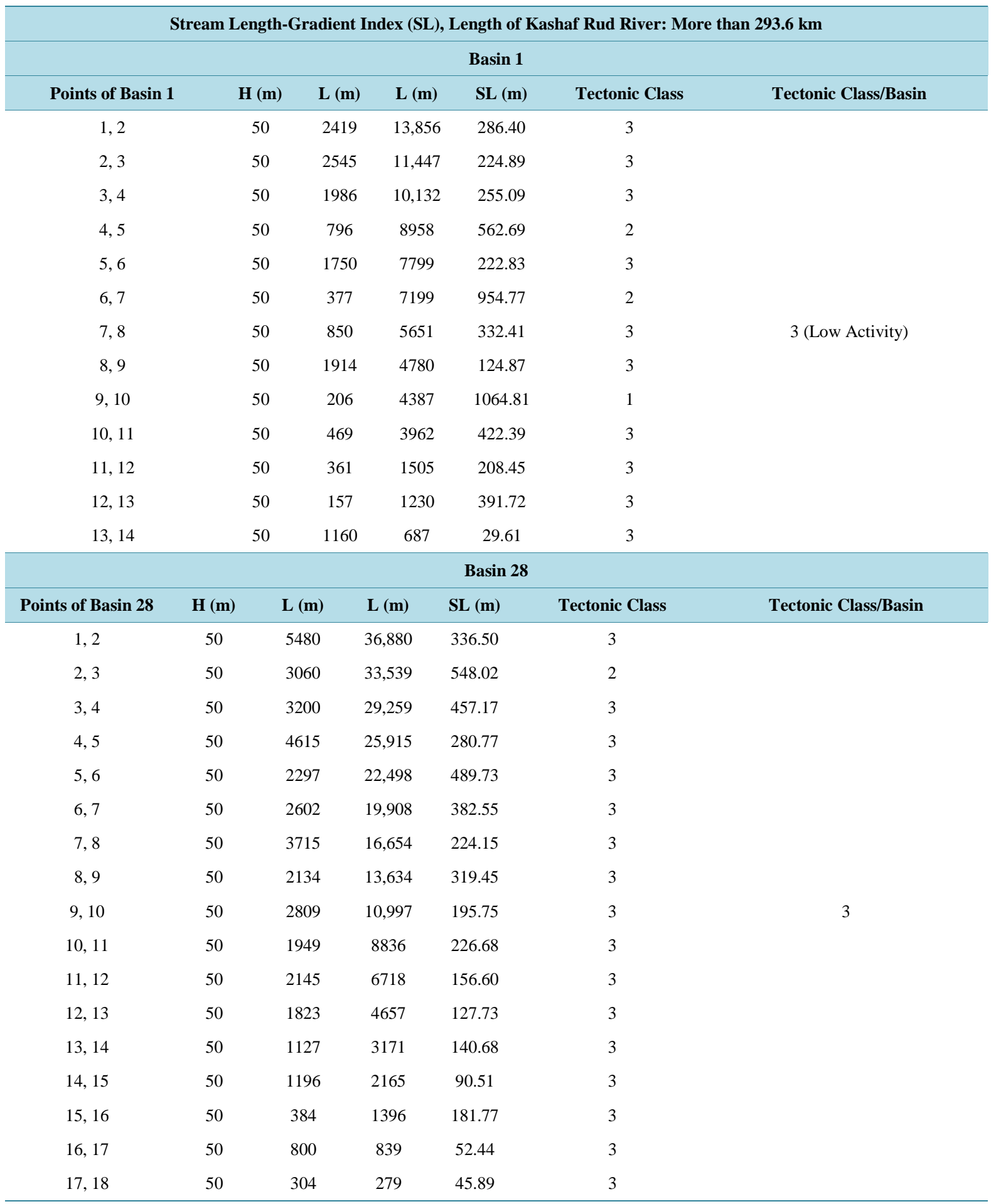

SL classification $\rightarrow 1$ (High Activity): > 1000, 2 (Moderate Activity): 500 - 1000, 3 (Low Activity): <500

$$
\mathrm{Vf}=2 \mathrm{Vfw} /(\text { Eld }+ \text { Erd }-2 \mathrm{Esc})
$$

where Vfw is the width of the valley floor, and Eld, Erd and Esc are the altitudes of the left and right divisions (looking downstream) and the stream channel, respectively [102]. [4] found significant differences in Vf be- 
tween tectonically active and inactive mountain fronts. Also, they found significant differences in Vf between tectonically active and inactive mountain fronts, because a valley floor is narrowed due to rapid stream down cutting.

Vfw value is obtained by measuring the length of a line which cuts the river and limits to two sides of a contour through which the river crosses (Table 2). In this research, $\mathrm{Vf}$ values are divided into 3 classes: 1 ( $\mathrm{Vf}<0.5$ ), $2(0.5<\mathrm{Vf}<1)$, and $3(\mathrm{Vf}>1)$. Therefore, all of the valleys are in 1 class and show $\mathrm{V}$-shape valleys (Figure 5$)$.

\subsection{Mountain-Front Sinuosity Index (Smf)}

This index represents a balance between stream erosion processes tending to cut some parts of a mountain front and active vertical tectonics that tend to produce straight mountain fronts. Index of mountain front sinuosity [3] is defined by:

$$
\mathrm{Smf}=\mathrm{Lj} / \mathrm{Ls}
$$

Table 2. Values of Vf index for sub-basins No.1 to 4.

\begin{tabular}{|c|c|c|c|c|c|c|c|c|}
\hline Basin & Number & $V_{\mathrm{fw}}(\mathbf{m})$ & $E_{l d}(m)$ & $E_{r d}(m)$ & $E_{s c}(m)$ & $V_{f}(m)$ & Tectonic CLASS & Tectonic Class/Basin \\
\hline 1 & $\mathrm{P} 1$ & 70 & 1433 & 1410 & 1382 & 1.77 & 3 & 3 (Low Activity) \\
\hline \multirow{2}{*}{2} & $\mathrm{P} 1$ & 200 & 1286 & 1281 & 1254 & 6.78 & 3 & \multirow{2}{*}{3} \\
\hline & P2 & 8 & 1236 & 1235 & 1233 & 3.20 & 3 & \\
\hline \multirow[t]{3}{*}{3} & $\mathrm{P} 1$ & 80 & 1277 & 1289 & 1258 & 3.20 & 3 & \multirow[t]{4}{*}{3} \\
\hline & $\mathrm{P} 1$ & 20 & 2937 & 2900 & 2891 & 0.73 & 2 & \\
\hline & P2 & 100 & 2781 & 2571 & 2325 & 0.28 & 1 & \\
\hline \multirow{4}{*}{4} & P3 & 70 & 2336 & 2145 & 2155 & 0.82 & 2 & \\
\hline & P4 & 60 & 2513 & 2437 & 2301 & 0.34 & 1 & \multirow{3}{*}{2 (Moderate Activity) } \\
\hline & P5 & 70 & 2158 & 2195 & 2005 & 0.41 & 1 & \\
\hline & P6 & 100 & 1601 & 1555 & 1451 & 0.79 & 2 & \\
\hline
\end{tabular}

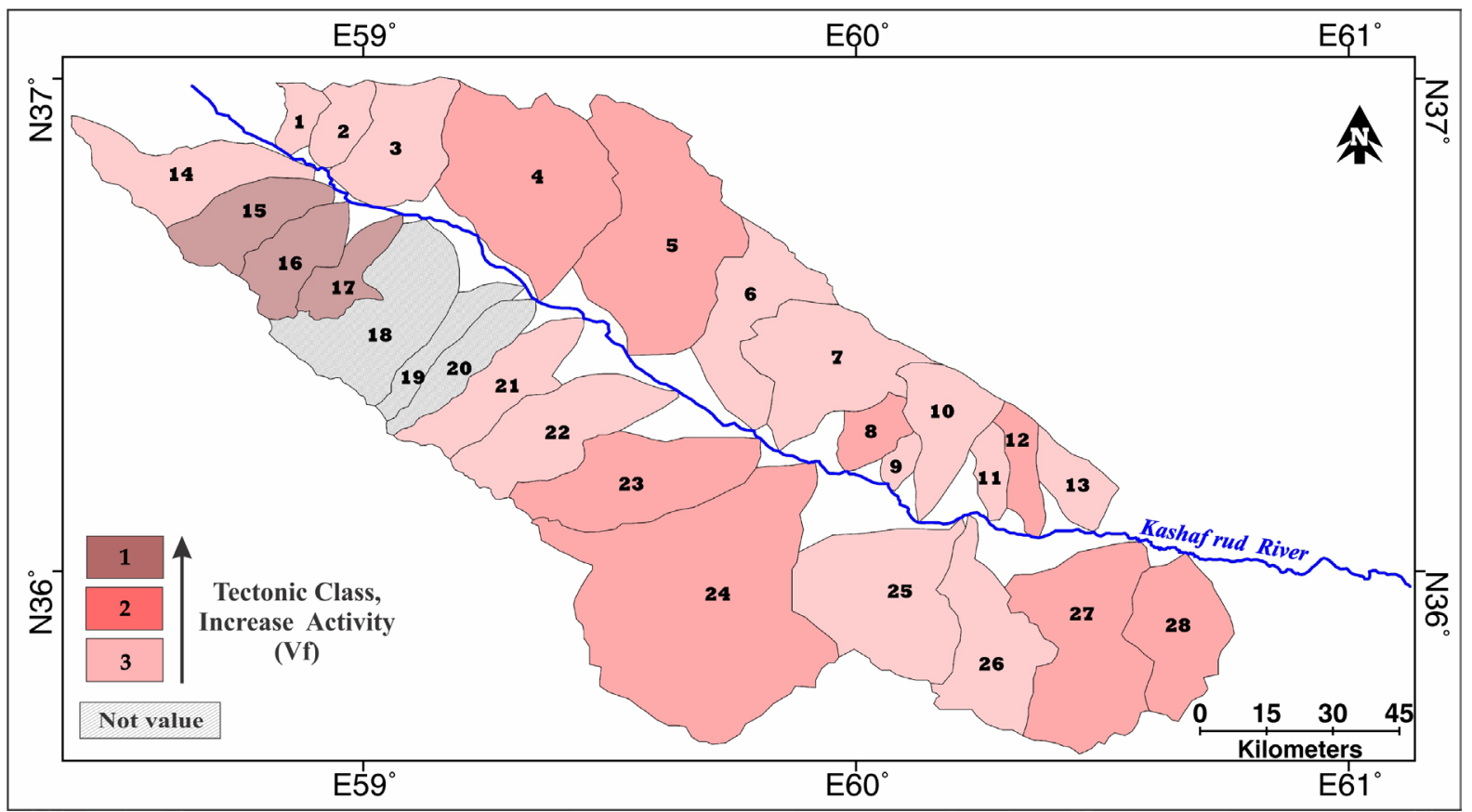

Figure 5. Classification map for the valley floor width to valley height ratio. 
where $\mathrm{Lj}$ is the planimetric length of the mountain along the mountain-piedmont junction, and Ls is the straightline length of the front. The Mountain fronts map of the study area has drawn in Figure 6. Smf is commonly less than 3, and approaches 1 where steep mountains rise rapidly along a fault or fold [102]. Therefore, this index can play an important role in tectonic activity. Considering that mountain fronts sites are independent from basins places, chances are some of them have various fronts (Table 3). Values of Smf are readily calculated from topographic maps for sub-basins. In this research, Smf values are divided into 3 classes: 1 (Smf < 1.53), 2 (1.53 $<\mathrm{Smf}<2.3$ ), and $3(\mathrm{Smf}>2.3)$ and in the study area most of the obtained values are in 3 class (Figure 7).

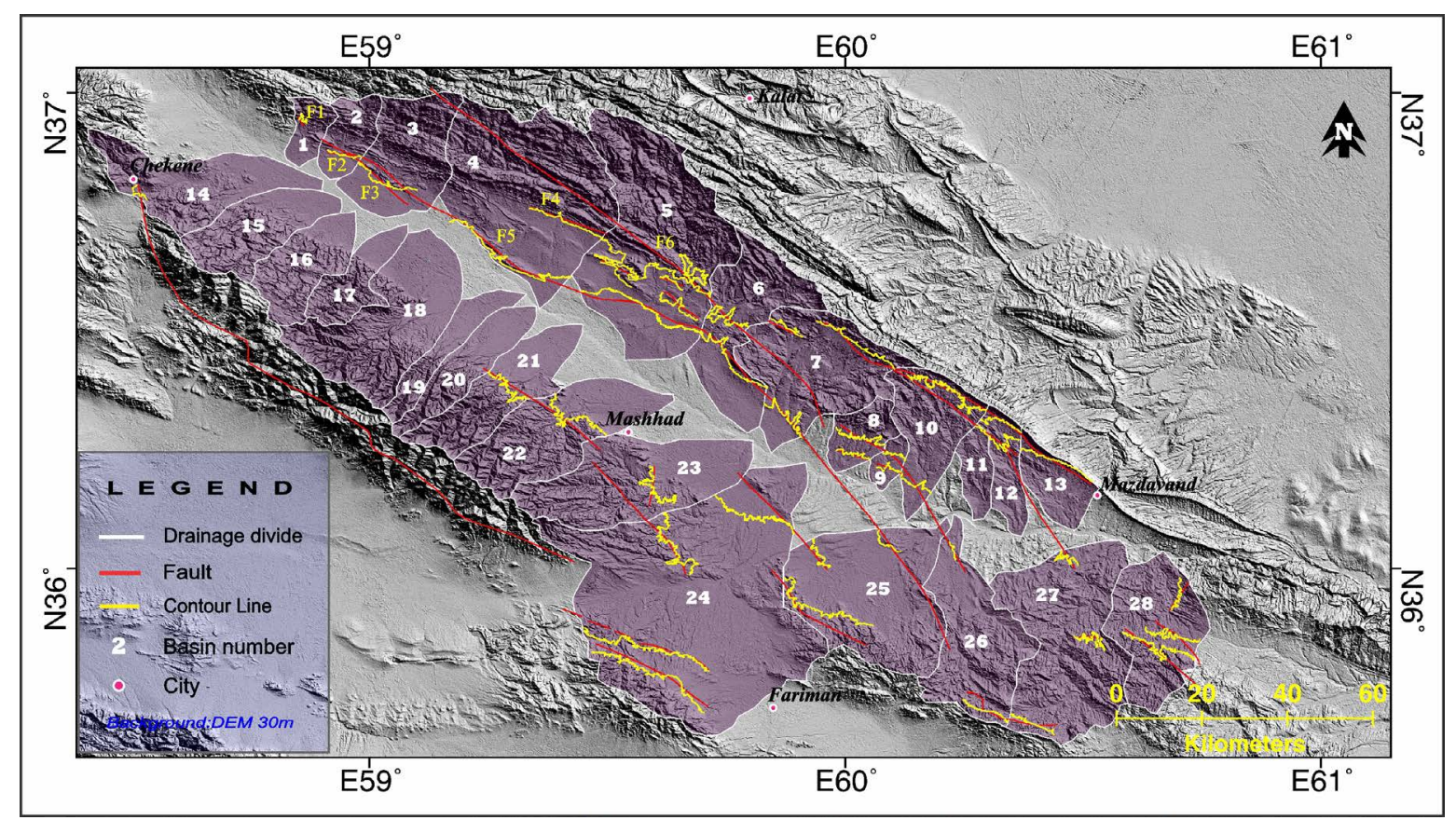

Figure 6. Position map for Mountain-fronts of study area.

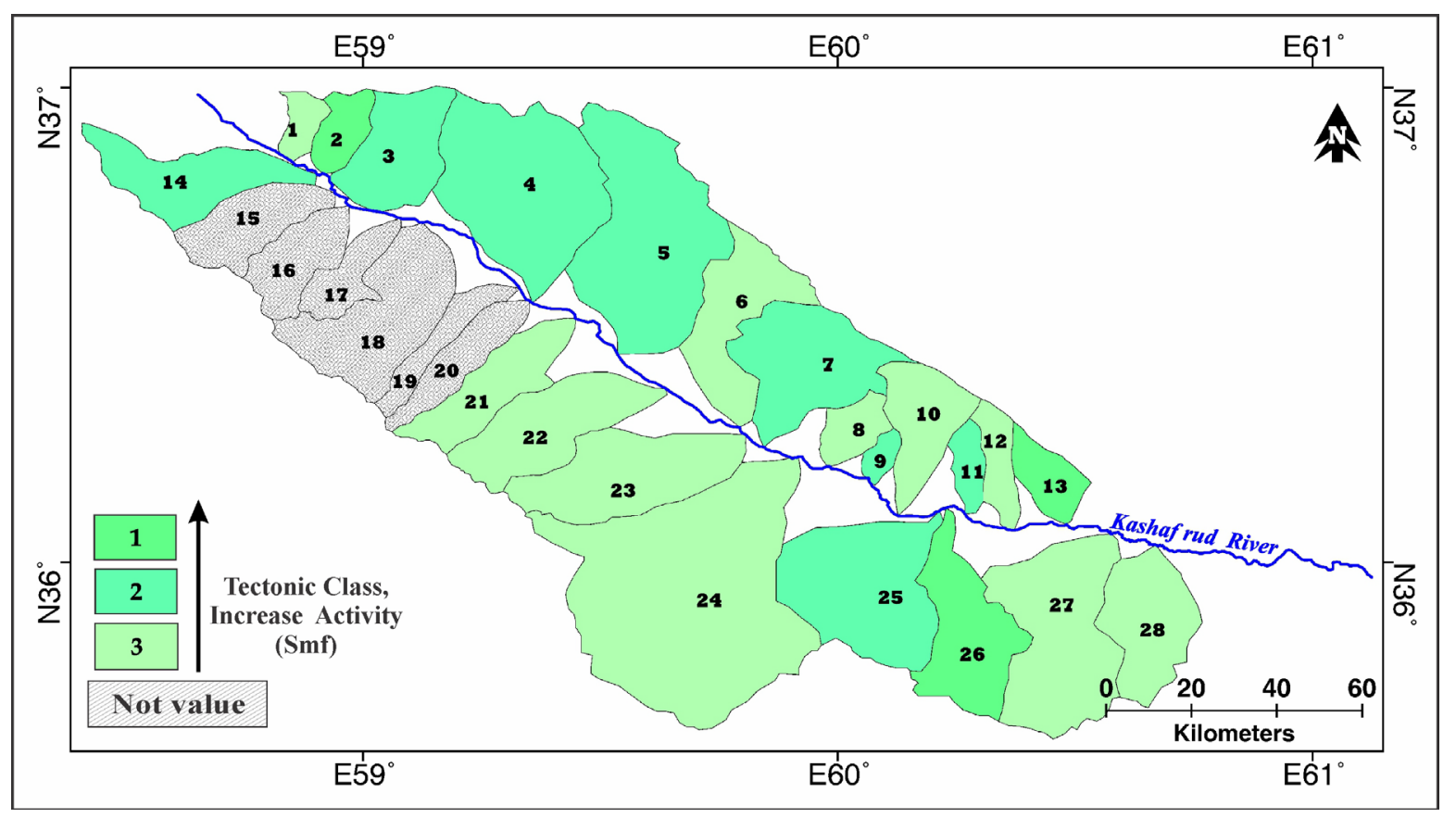

Figure 7. Classification map for Mountain-front sinuosity index. 
Table 3. Values of Smf index for sub-basins No. 1 to 4.

\begin{tabular}{|c|c|c|c|c|c|c|c|}
\hline \multicolumn{8}{|c|}{ Mountain Front Sinuosity (Smf) } \\
\hline Basin & Fault & Segment & $\mathbf{L}_{\mathrm{mf}}(\mathbf{m})$ & $\mathbf{L}_{\mathrm{s}}(\mathbf{m})$ & $\mathrm{S}_{\mathrm{mf}} /$ segment & Average of $S_{\mathrm{mf}} /$ Basin & Tectonic class \\
\hline 1 & F1 & $1(1490 \mathrm{~m})$ & 6400 & 1626 & 3.94 & 3.94 & 3 (Low Activity) \\
\hline 2 & F2 & $1(1250 \mathrm{~m})$ & 8600 & 6540 & 1.31 & 1.31 & 1 (High Activity) \\
\hline 3 & F3 & $1(1220 \mathrm{~m})$ & 20,930 & 12,640 & 1.66 & 1.66 & 2 (Moderate Activity) \\
\hline \multirow{2}{*}{4} & F4 & $1(1330 \mathrm{~m})$ & 20,660 & 15,360 & 1.35 & \multirow{2}{*}{1.60} & \multirow{2}{*}{2} \\
\hline & F5 & $1(1130 \mathrm{~m})$ & 48,530 & 26,080 & 1.86 & & \\
\hline
\end{tabular}

\subsection{Asymmetry Factor (Af)}

This index is related to two tectonics and none tectonic factors. None tectonic factors may relate to lithology and rock fabrics. It is a way to evaluate the existence of tectonic tilting at the scale of a drainage basin. The index is defined as follows:

$$
\text { Af }=(\text { Ar/At }) 100
$$

where Ar is the right side area of the master stream basin (looking downstream) and At is the total area of the basin that can be measured by GIS software. To calculate this index in the area At and Ar are obtained using the sub-basins and the master river maps. Af is close to 50 if there is no or little tilting perpendicular to the direction of the master stream. Af is significantly greater or smaller than 50 under the effects of active tectonics or strong lithologic control. The values of this index are divided into three categories. 1 : $(\mathrm{Af}>15) 2$ : $(7<\mathrm{Af}<15)$ and 3 : $($ Af $<7)$.

Among the obtained values (Table 4), a map has prepared that it shows Asymmetry factor of study area (Figure 8).

\subsection{Basin Shape Index (Bs)}

Relatively young drainage basins in active tectonic areas tend to be more elongated than their normal shape to the topographic slope of a mountain. The elongated shape tends to evolve into a more circular shape [4]. The horizontal projection of the basin shape may be described by the basin shape index or the elongation ratio, Bs [7]. The calculation formula is:

$$
\mathrm{Bs}=\mathrm{Bl} / \mathrm{Bw}
$$

where $\mathrm{Bl}$ is the length of the basin measured from the headwater to the mount, and $\mathrm{Bw}$ is basin width in the widest point of the basin.

To calculate this index in the area, $\mathrm{Bl}$ and $\mathrm{Bw}$ are obtained using the sub-basins (Table 5) and the master river maps then the values are divided into 3 classes. 1: (Bs $>4)$ 2: $(3<\mathrm{Bs}<4)$ 3: $(\mathrm{Bs}<3)$, based on [11]. According to Figure 9, this index has calculated and the maximum value belongs to sub-basin No. 19 (Class 1 in Figure 10).

\subsection{Hypsometric Integral Index (Hi)}

The hypsometric integral (Hi) describes the relative distribution of elevation in a given area of a landscape particularly a drainage basin. The index is defined as the relative area below the hypsometric curve and it is an important indicator for topographic maturity. $\mathrm{H}_{\max }, \mathrm{H}_{\min }$ and $\mathrm{H}_{\text {ave }}$ are calculated on DEM. This index is calculated to all sub-basins in the area. The hypsometric integral reveals the maturity stages of topography that can, indirectly, be an indicator of active tectonics.

In general, high values of the hypsometric integral are convex, and these values are generally $>0.5$. Intermediate values tend to be more concave-convex or straight, and generally have values between 0.4 and 0.5 . Finally, lower values $(<0.4)$ tend to have concave shapes [11]. We can consider class 1 for $\mathrm{Hi}>0.5$, class 2 for $\mathrm{Hi}$ between 0.4 and 0.5 and class 3 for $\mathrm{Hi}<0.4$ and so, sub-basin No.11 shows younger topography (Table 6, Figure 11). 
Table 4. Values of Af index for sub-basins No. 1 to 6.

\begin{tabular}{ccccccc}
\hline \multicolumn{7}{c}{ Asymmetry Factor (AF) } \\
\hline Basin & $\left.\mathbf{A}_{\mathbf{r}} \mathbf{( s q} \mathbf{~ k m}\right)$ & $\left.\mathbf{A}_{\mathbf{t}} \mathbf{( s q} \mathbf{~ k m}\right)$ & $\mathbf{A F}$ & Tilting Part & Flow Direction of River & Tectonic Class \\
\hline $\mathbf{1}$ & 22.19 & 97.55 & 22.75 & west & $\mathrm{N} \rightarrow \mathrm{S}$ & 1 (High Activity) \\
$\mathbf{2}$ & 80.27 & 155.93 & 51.48 & east & $\mathrm{N} \rightarrow \mathrm{S}$ & (Low Activity) \\
$\mathbf{3}$ & 99.7 & 431.5 & 23.11 & west & $\mathrm{N} \rightarrow \mathrm{S}$ & 1 \\
$\mathbf{4}$ & 786.6 & 1023.7 & 76.84 & east & $\mathrm{N} \rightarrow \mathrm{S}$ & $\mathrm{N} \rightarrow \mathrm{S}$ \\
$\mathbf{5}$ & 696.5 & 1098.7 & 63.39 & east & NE $\rightarrow \mathrm{SE}$ & 2 (Moderate Activity) \\
$\mathbf{6}$ & 311.2 & 498.6 & 62.41 & east & & 2 \\
\hline
\end{tabular}

Table 5. Values of Bs index.

\begin{tabular}{|c|c|c|c|c|}
\hline \multicolumn{5}{|c|}{ Drainage Basin Shape (Bs) } \\
\hline Basin & BI (m) & BW (m) & Bs & Tectonic Class \\
\hline 1 & 16,580 & 8430 & 1.97 & 3 (Low Activity) \\
\hline 2 & 21,400 & 9850 & 2.17 & 3 \\
\hline 3 & 32,350 & 16,670 & 1.94 & 3 \\
\hline 4 & 47,180 & 34,380 & 1.37 & 3 \\
\hline 5 & 59,070 & 25,880 & 2.28 & 3 \\
\hline 6 & 47,710 & 26,670 & 1.79 & 3 \\
\hline 7 & 34,380 & 30,860 & 1.11 & 3 \\
\hline 8 & 19,670 & 12,660 & 1.55 & 3 \\
\hline 9 & 13,790 & 6520 & 2.12 & 3 \\
\hline 10 & 35,040 & 20,540 & 1.71 & 3 \\
\hline 11 & 22,480 & 6930 & 3.24 & 2 (Moderate Activity) \\
\hline 12 & 31,370 & 8410 & 3.73 & 2 \\
\hline 13 & 26,100 & 11,600 & 2.25 & 3 \\
\hline 14 & 34,130 & 30,700 & 1.11 & 3 \\
\hline 15 & 31,620 & 16,970 & 1.86 & 3 \\
\hline 16 & 30,060 & 15,920 & 1.89 & 3 \\
\hline 17 & 28,510 & 14,390 & 1.98 & 3 \\
\hline 18 & 40,390 & 27,540 & 1.47 & 3 \\
\hline 19 & 39,570 & 6390 & 6.19 & 1 (High Activity) \\
\hline 20 & 39,910 & 8330 & 4.79 & 1 \\
\hline 21 & 43,500 & 14,090 & 3.09 & 2 \\
\hline 22 & 41,240 & 17,940 & 2.30 & 3 \\
\hline 23 & 47,830 & 20,770 & 2.30 & 3 \\
\hline 24 & 63,390 & 61,390 & 1.03 & 3 \\
\hline 25 & 38,620 & 37,440 & 1.03 & 3 \\
\hline 26 & 50,780 & 18,930 & 2.68 & 3 \\
\hline 27 & 49,160 & 24,170 & 2.03 & 3 \\
\hline 28 & 38,040 & 20,500 & 1.86 & 3 \\
\hline
\end{tabular}


Table 6. Values of Hi index for sub-basin No. 11.

\begin{tabular}{cccccc}
\hline \multicolumn{5}{c}{ Hypsometric Integration of Basin 11 } \\
\hline $\mathbf{h}(\mathbf{m})$ & $\mathbf{h}_{\mathbf{0}}(\mathbf{m})$ & $\mathbf{h}_{\mathbf{0}} / \mathbf{H}(\mathbf{m})$ & $\mathbf{a}\left(\mathbf{k m}^{\mathbf{2}}\right)$ & $\mathbf{A ~ ( \mathbf { k m } ^ { 2 } )}$ & $\mathbf{a} / \mathbf{A}\left(\mathbf{k m}^{\mathbf{2}}\right)$ \\
\hline 900 & 0 & 0.00 & 29.21 & & 1.00 \\
1200 & 300 & 0.50 & 78 & 108.64 & 0.73 \\
1500 & 600 & 1.00 & 1.1 & & 0.01 \\
\hline
\end{tabular}
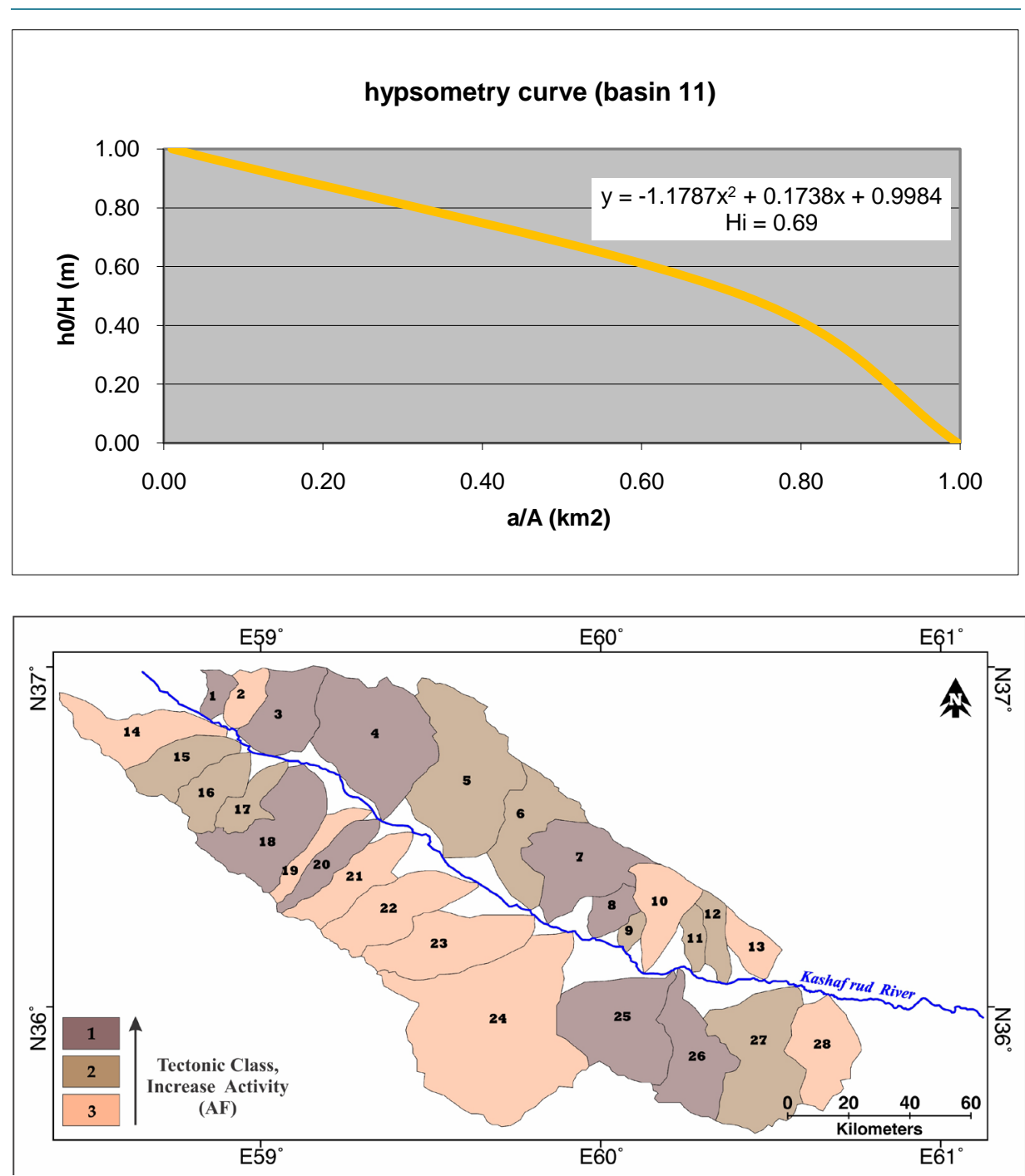

Figure 8. Classification map for Asymmetry factor index.

\subsection{Transverse Topographic Symmetry Factor (T)}

The transverse topographic symmetry factor $(\mathrm{T})$ was calculated as follows:

$$
\mathrm{T}=\mathrm{Da} / \mathrm{Dd}
$$

where Da is the space from the midline of the drainage basin to the midline of the active belt and Dd is the space from the midline to the basin limit [104]. In a completely symmetric basin $T=0$ and as asymmetry increases $T$ approaches to value of 1.0. We can consider class 1 for $\mathrm{T}>0.4$, class 2 for $\mathrm{T}$ between 0.2 and 0.4 and class 3 for $\mathrm{T}<0.2$ and so, sub-basin No. 3 shows higher activity (Table 7, Figure 12 and Figure 13). 


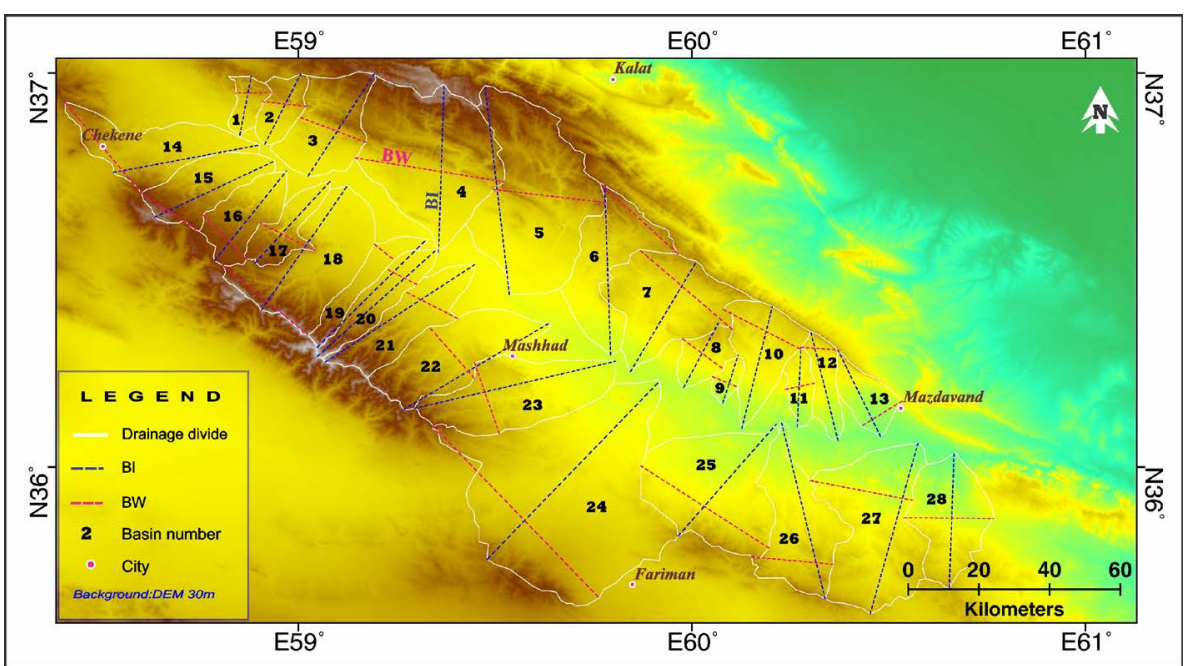

Figure 9. Basic map for Basin shapeindex calculation.

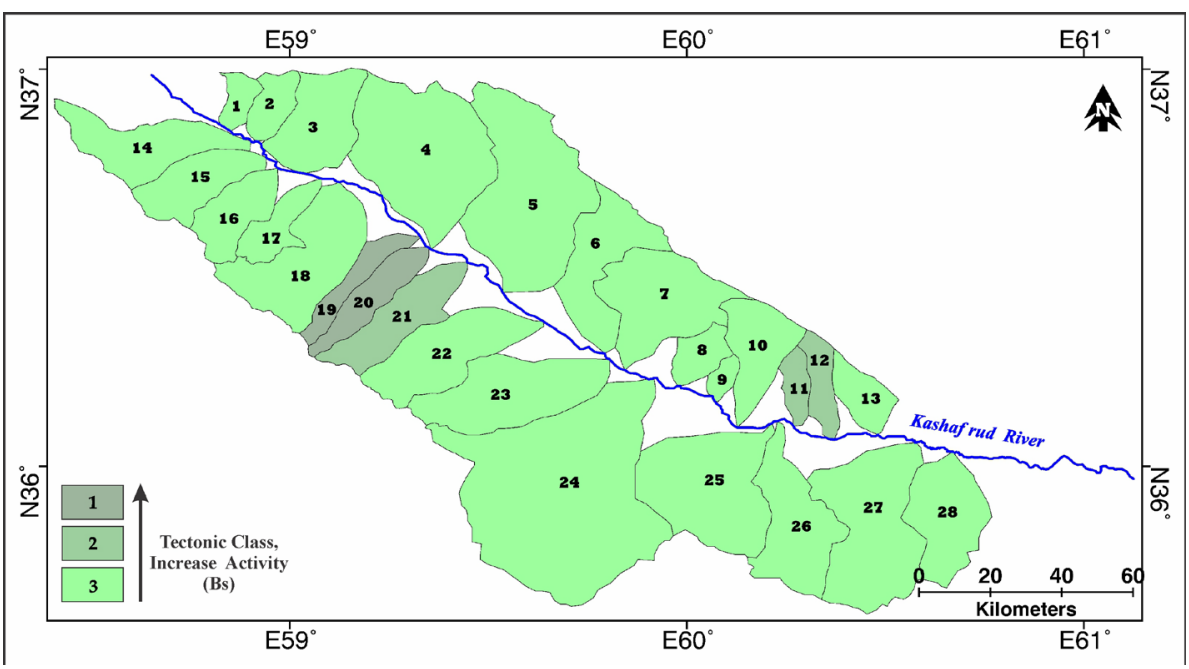

Figure 10. Classification map for Basin shapeindex.

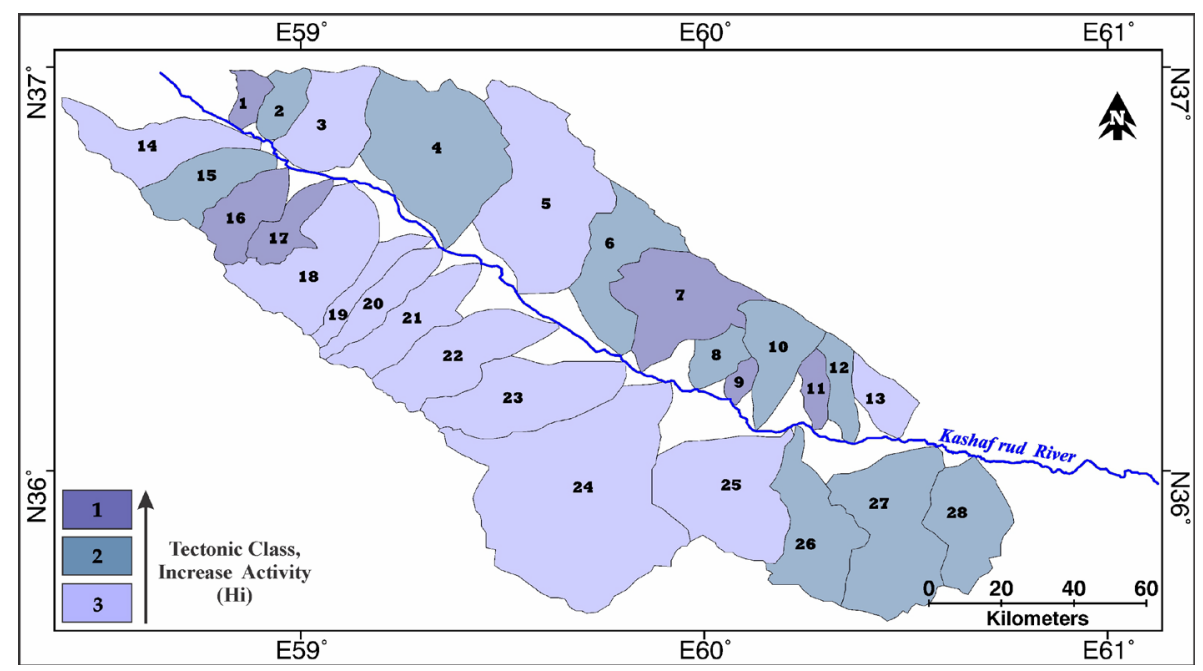

Figure 11. The hypsometric integral classification map for study area. 


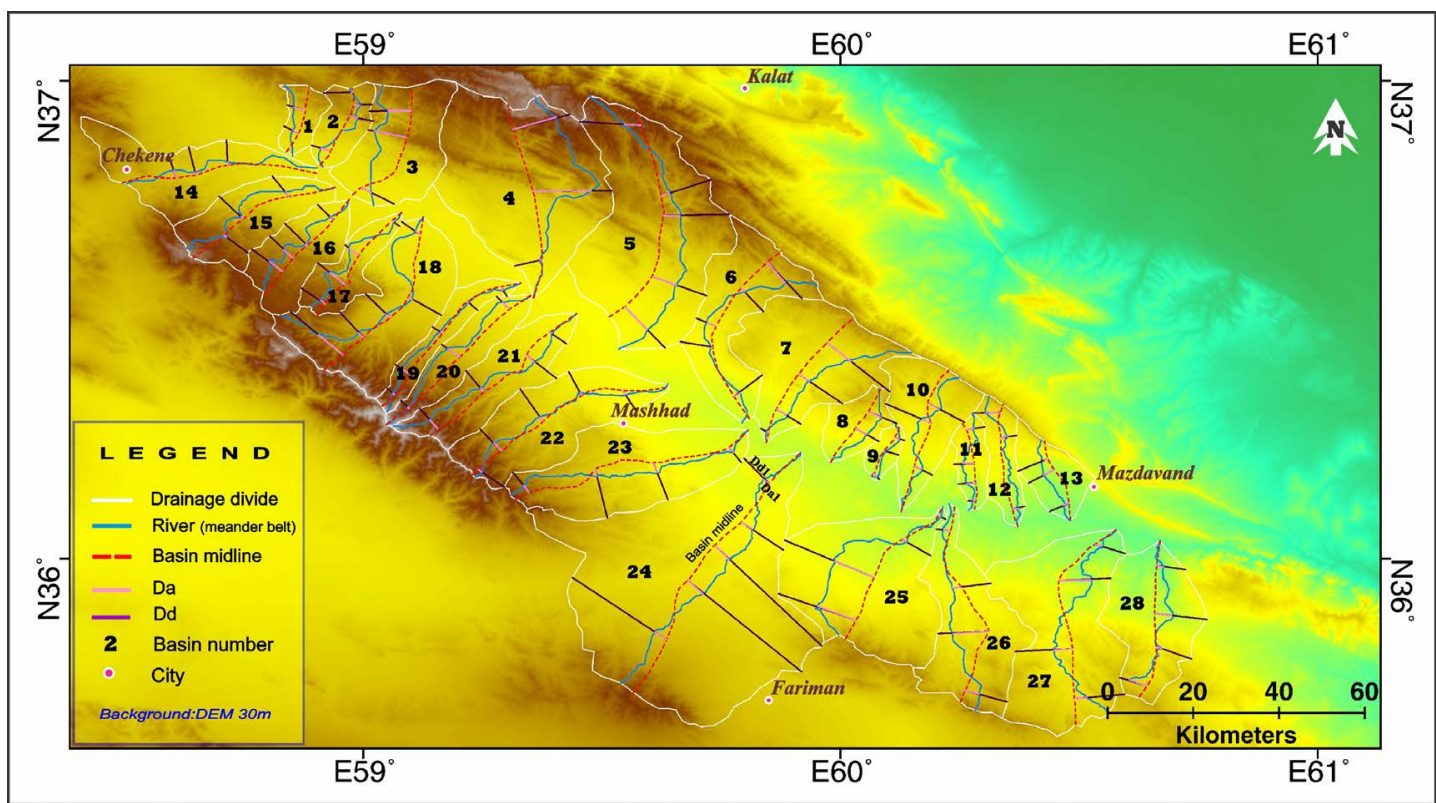

Figure 12. Basic map for Tindex calculation.

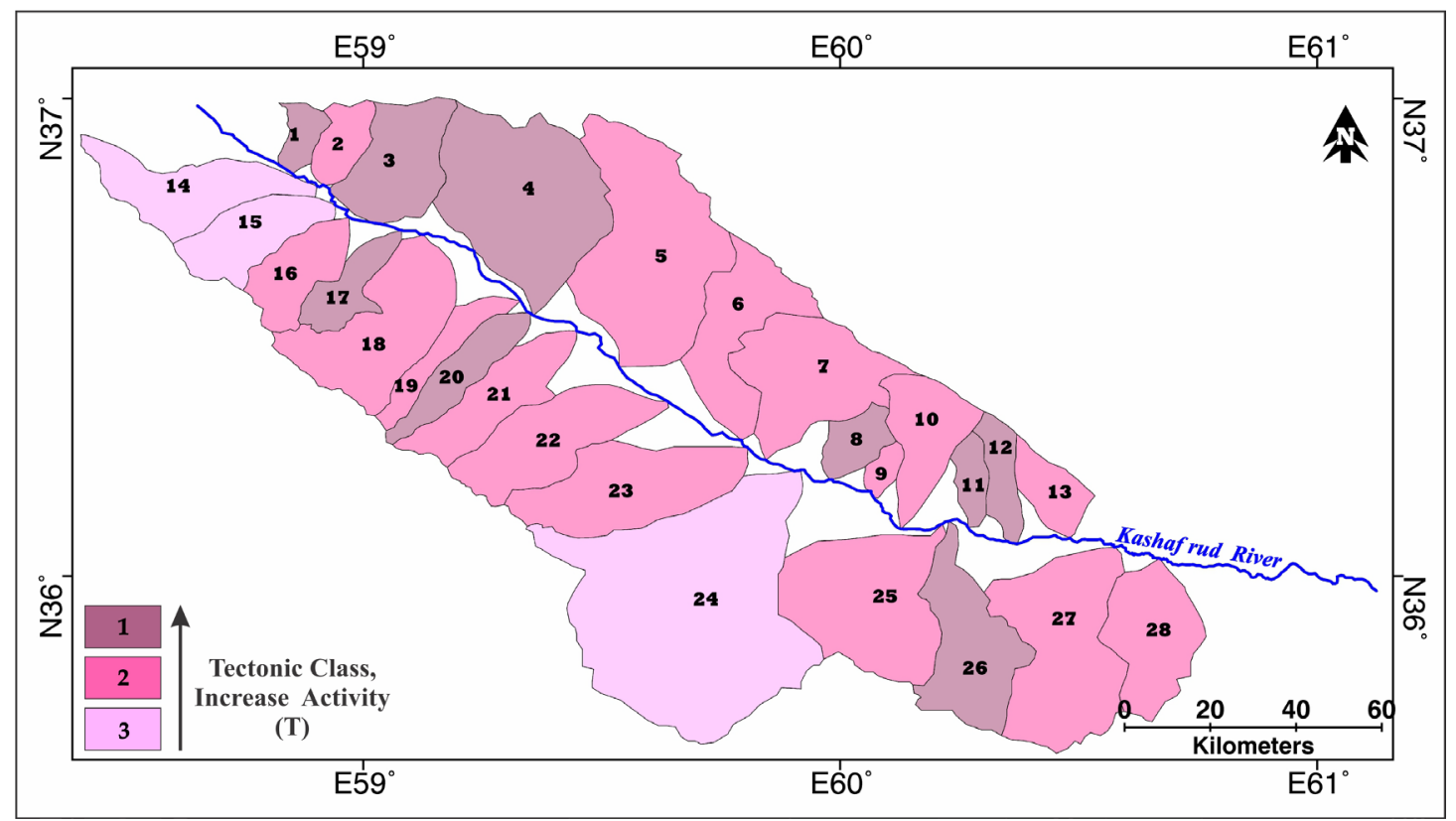

Figure 13. Classification map for Tindex.

\section{Results and Discussion}

The average of the seven measured geomorphic indices (Vf, Smf, SL, Af, Bs, Hi and T) was used to evaluate the distribution of relative tectonic activity. Through averaging these seven indices (Table 8), we obtain one index that is known as modified index of active tectonics (Miat). The values of the index were divided into four classes to define the degree of active tectonics: 1 -high $(1<$ Iat $<1.5)$, 2-moderate $(1.5<$ Iat $<2.5)$ and 3-low $(2.5<$ Iat $)$.

Thus, there are low relative tectonic activities in sub-basin No. 6, 10, 13, 14, 21, 22, 23, 24 \& 28 and moderate relative tectonic activities in the other sub-basins (Figure 14). These sub-basins have got the more active uplifting by Cimmerian-Eurasian convergent movements. These uplifting are related to active faults and folds [105] [106]. 


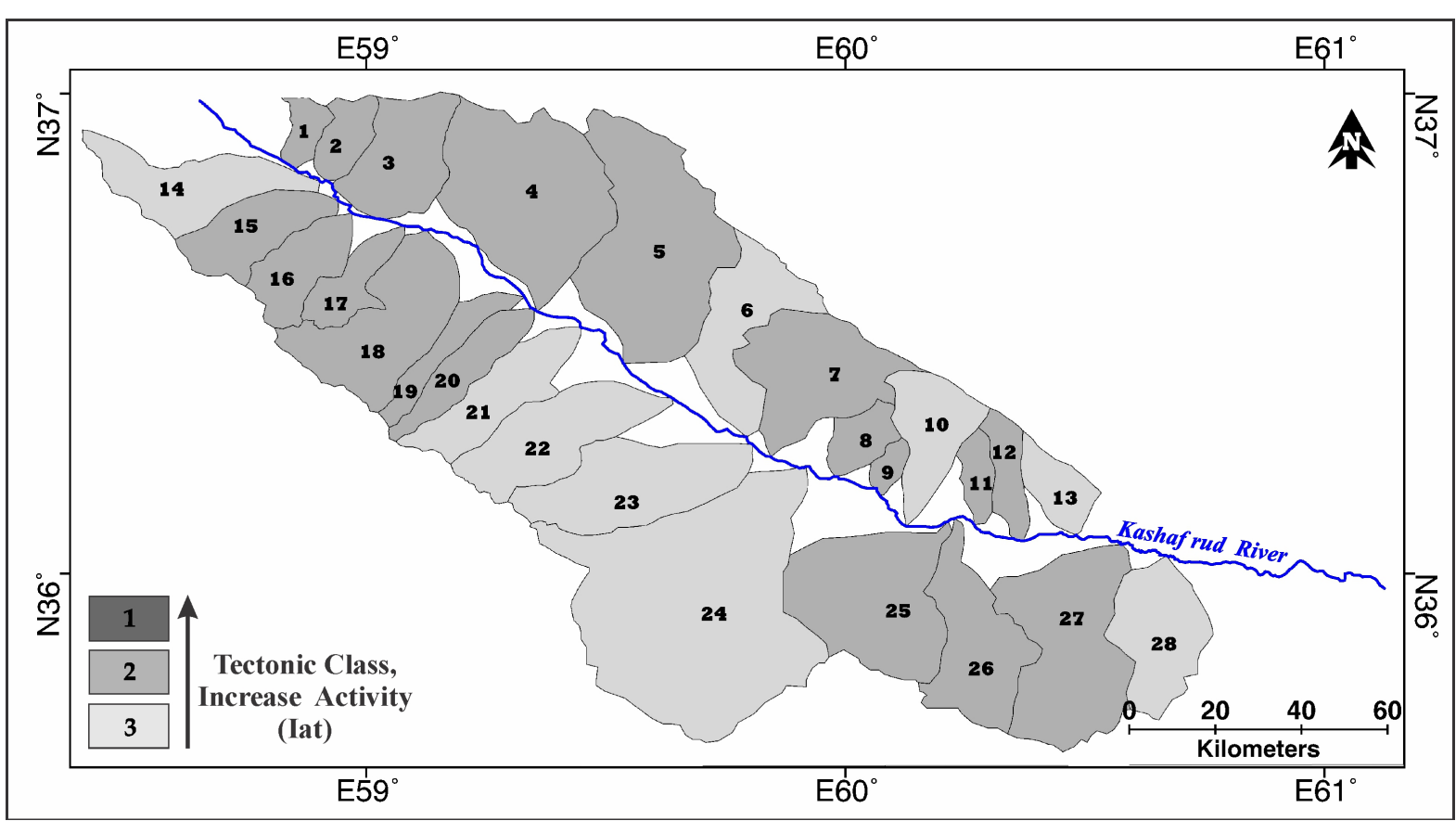

Figure 14. Relative tectonic activity classification and fault map of study area.

Table 7. Values of $\mathrm{T}$ index for 5 sub-basins.

\begin{tabular}{|c|c|c|c|c|c|c|}
\hline \multicolumn{7}{|c|}{ Transverse Topographic Symmetry Factor (T) } \\
\hline Basin & Number & Da (m) & Dd (m) & $\mathbf{T}(\mathbf{m})$ & $\mathbf{T}_{\text {ave }}(\mathbf{m})$ & Tectonic Class \\
\hline \multirow{2}{*}{1} & 1 & 2270 & 3589 & 0.63 & \multirow{2}{*}{0.52} & \multirow{2}{*}{1 (High Activity) } \\
\hline & 2 & 1289 & 3179 & 0.41 & & \\
\hline \multirow{4}{*}{2} & 1 & 299 & 5520 & 0.05 & \multirow{4}{*}{0.31} & \multirow{4}{*}{2 (Moderate Activity) } \\
\hline & 2 & 1172 & 3405 & 0.34 & & \\
\hline & 3 & 1543 & 4602 & 0.34 & & \\
\hline & 4 & 1956 & 3860 & 0.51 & & \\
\hline \multirow{3}{*}{3} & 1 & 4386 & 7830 & 0.56 & \multirow{3}{*}{0.57} & \multirow{3}{*}{1} \\
\hline & 2 & 6280 & 7480 & 0.84 & & \\
\hline & 3 & 2178 & 7200 & 0.30 & & \\
\hline \multirow{3}{*}{4} & 1 & 8530 & 11,010 & 0.77 & \multirow{3}{*}{0.53} & \multirow{3}{*}{1} \\
\hline & 2 & 10,920 & 14,770 & 0.74 & & \\
\hline & 3 & 427 & 5280 & 0.08 & & \\
\hline \multirow{5}{*}{5} & 1 & 3091 & 11,440 & 0.27 & \multirow{5}{*}{0.34} & \multirow{5}{*}{2} \\
\hline & 2 & 1602 & 10,110 & 0.16 & & \\
\hline & 3 & 3082 & 12,290 & 0.25 & & \\
\hline & 4 & 5010 & 11,210 & 0.45 & & \\
\hline & 5 & 6810 & 12,200 & 0.56 & & \\
\hline
\end{tabular}

Also, based on [96], this area is a moderate seismic risk zone with following seismicity parameter: $b=0.83$, $\mathrm{M} \max =7.5$. Focal mechanisms of several earthquakes are dextral strike slip faulting such as Garmkhan-e Bojnourd $(\mathrm{Ms}=6.4,1996)$ and thrusting. This region experiences low to moderate earthquakes with high frequency, 
Table 8. Relative tectonic activity classification.

\begin{tabular}{|c|c|c|c|c|c|c|c|c|c|}
\hline Sub-Basins & $\begin{array}{c}\text { Class of } \\
V_{f}\end{array}$ & $\begin{array}{c}\text { Class of } \\
\mathrm{S}_{\mathrm{mf}}\end{array}$ & $\begin{array}{c}\text { Class of } \\
\mathrm{H}_{\mathrm{i}}\end{array}$ & $\begin{array}{c}\text { Class of } \\
B_{s}\end{array}$ & $\begin{array}{c}\text { Class of } \\
\mathrm{AF}\end{array}$ & $\begin{array}{c}\text { Class of } \\
\text { SL }\end{array}$ & $\begin{array}{c}\text { Class of } \\
\mathrm{T}\end{array}$ & $\mathrm{S} / \mathrm{n}$ & Iat Index \\
\hline 1 & 3 & 3 & 1 & 3 & 1 & 3 & 1 & 2.14 & 2 \\
\hline 2 & 3 & 1 & 2 & 3 & 3 & 3 & 2 & 2.43 & 2 \\
\hline 3 & 3 & 2 & 3 & 3 & 1 & 3 & 1 & 2.29 & 2 \\
\hline 4 & 2 & 2 & 2 & 3 & 1 & 2 & 1 & 1.86 & 2 \\
\hline 5 & 2 & 2 & 3 & 3 & 2 & 2 & 2 & 2.29 & 2 \\
\hline 6 & 3 & 3 & 2 & 3 & 2 & 3 & 2 & 2.57 & 3 \\
\hline 7 & 3 & 2 & 1 & 3 & 1 & 3 & 2 & 2.14 & 2 \\
\hline 8 & 2 & 3 & 2 & 3 & 1 & 3 & 1 & 2.14 & 2 \\
\hline 9 & 3 & 2 & 1 & 3 & 2 & 3 & 2 & 2.29 & 2 \\
\hline 10 & 3 & 3 & 2 & 3 & 3 & 2 & 2 & 2.57 & 3 \\
\hline 11 & 3 & 2 & 1 & 2 & 2 & 3 & 1 & 2.00 & 2 \\
\hline 12 & 2 & 3 & 2 & 2 & 2 & 3 & 1 & 2.14 & 2 \\
\hline 13 & 3 & 1 & 3 & 3 & 3 & 3 & 2 & 2.57 & 3 \\
\hline 14 & 3 & 2 & 3 & 3 & 3 & 3 & 3 & 2.86 & 3 \\
\hline 15 & 1 & - & 2 & 3 & 2 & 2 & 3 & 2.17 & 2 \\
\hline 16 & 1 & - & 1 & 3 & 2 & 2 & 2 & 1.83 & 2 \\
\hline 17 & 1 & - & 1 & 3 & 2 & 2 & 1 & 1.67 & 2 \\
\hline 18 & - & - & 3 & 3 & 1 & 3 & 2 & 2.40 & 2 \\
\hline 19 & - & - & 3 & 1 & 3 & 2 & 2 & 2.20 & 2 \\
\hline 20 & - & - & 3 & 1 & 1 & 2 & 1 & 1.60 & 2 \\
\hline 21 & 3 & 3 & 3 & 2 & 3 & 2 & 2 & 2.57 & 3 \\
\hline 22 & 3 & 3 & 3 & 3 & 3 & 3 & 2 & 2.86 & 3 \\
\hline 23 & 2 & 3 & 3 & 3 & 3 & 3 & 2 & 2.71 & 3 \\
\hline 24 & 2 & 3 & 3 & 3 & 3 & 3 & 3 & 2.86 & 3 \\
\hline 25 & 3 & 2 & 3 & 3 & 1 & 3 & 2 & 2.43 & 2 \\
\hline 26 & 3 & 1 & 2 & 3 & 1 & 3 & 1 & 2.00 & 2 \\
\hline 27 & 2 & 3 & 2 & 3 & 2 & 3 & 2 & 2.43 & 2 \\
\hline 28 & 2 & 3 & 2 & 3 & 3 & 3 & 2 & 2.57 & 3 \\
\hline
\end{tabular}

short repeat time and down to $20 \mathrm{Km}$ focal depth. Sometimes in northern margin of south Caspian basin, focal depths exceed to $70 \mathrm{Km}$ which is a depiction of its subduction. Intensity of earthquakes is in low levels.

The most serious seismic hazards in this province, which contains large city such as Mashhad are landslide in high regions, settlement in some plains, and surface faulting.

\section{Conclusions}

The calculated geomorphic indices are suitable for assessment of tectonic activity of the study area. The seven geomorphic indices: stream-gradient index (Sl), valley floor width-valley height ratio (Vf) and mountain-front sinuosity (Smf), drainage basin asymmetry (Af), hypsometric integral (Hi), drainage basin shape (Bs) and transverse topographic symmetry factor $(\mathrm{T})$ have calculated in Kashaf rud river.

Therefore, firstly the area was divided to 28 sub-basins and for each one, indices were calculated, then all of the indices were divided into relative tectonic activity classes. Afterwards, the seven measured indices for each 
sub-basin were compounded and a unit index obtained as the modified index of active tectonics (Miat) for the first time. According to this index, there are low and moderate relative tectonic activities levels.

Low relative tectonic activities level has been fund in sub-basin No. 6, 10, 13, 14, 21, 22, 23, 24 \& 28 and moderate relative tectonic activities level has been fund in the other sub-basins. It means that these sub-basins have got the more active uplifting by Cimmerian-Eurasian convergent movements, because they are on the longitudinal faults that have been formed above an old suture zone.

\section{Acknowledgements}

This work has funded by the Department of Geology, Science and Research Branch, Islamic Azad University, Tehran, Iran. Also, Special thanks to vice-president for research in Science and Research Branch, Tehran.

\section{References}

[1] Arian, M. (2013) Physiographic-Tectonic Zoning of Iran’s Sedimentary Basins. Open Journal of Geology, 3, $169-177$. http://dx.doi.org/10.4236/ojg.2013.33020

[2] Qorashi, M. and Arian, M. (2011) Tectonics of Iran. Geologic Survey of Iran, Tehran, 336 p.

[3] Arian, M. (2011) Basement Tectonics and Geology of Iran. Asar Nafis Press, Qum, 300 p.

[4] Bull, W.B. and McFadden, L.D. (1977) Tectonic Geomorphology North and South of the Garlock Fault, California. In: Doehring, D.O., Ed., Geomorphology in Arid Regions, Proceedings of the Eighth Annual Geomorphology Symposium, State University of New York, Binghamton, 115-138.

[5] Molin, P., Pazzaglia, F.J. and Dramis, F. (2004) Geomorphic Expression of Active Tectonics in a Rapidly-Deforming Forearc, Sila Massif, Calabria, Southern Italy. American Journal of Science, 304, 559-589. http://dx.doi.org/10.2475/ajs.304.7.559

[6] Silva, P.G., Goy, J.L., Zazo, C. and Bardajm, T. (2003) Fault Generated Mountain Fronts in Southeast Spain: Geomorphologic Assessment of Tectonic and Earthquake Activity. Geomorphology, 50, 203-225. http://dx.doi.org/10.1016/S0169-555X(02)00215-5

[7] Keller, E.A. and Pinter, N. (2002) Active Tectonics: Earthquakes, Uplift, and Landscape. Prentice Hall, New York, 432.

[8] Rockwell, T.K., Keller, E.A. and Jonson, D.L. (1985) Tectonic Geomorphology of Alluvial Fans and Mountain Fronts near Ventura, California. In: Morisawa, M. and Hack, J.T., Eds., Tectonic Geomorphology, Allen and Unwin Publishers, Boston, 183-207.

[9] Wells, S.G., Bullard, T.F., Menges, T.M., Drake, P.G., Karas, P.A., Kelson, K.I., Ritter, J.B. and Wesling, J.R. (1988) Regional Variations in Tectonic Geomorphology along Segmented Convergent Plate Boundary Pacific Coast of Costa Rica. Geomorphology, 1, 239-265. http://dx.doi.org/10.1016/0169-555X(88)90016-5

[10] Dehbozorgi, M., Pourkermani, M., Arian, M., Matkan, A.A., Motamedi, H. and Hosseiniasl, A. (2010) Quantitative Analysis of Relative Tectonic Activity in the Sarvestan Area, Central Zagros , Iran. Geomorphology, 121, 329-341. http://dx.doi.org/10.1016/j.geomorph.2010.05.002

[11] El Hamdouni, R., Irigaray, C., Fernandez, T., Chacon, J. and Keller, E.A. (2008) Assessment of Relative Active Tectonics, Southwest Border of the Sierra Nevada (Southern Spain). Geomorphology, 96, 150-173. http://dx.doi.org/10.1016/j.geomorph.2007.08.004

[12] Arian, M. (2011) A Preface on Salt Diapirism of Iran. Asar Nafis Press, Qum, 309 p.

[13] Arian, M. and Noroozpour, H. (2015) The Biggest Salt-Tongue Canopy of Central Iran. Open Journal of Geology, 5, 55-60. http://dx.doi.org/10.4236/ojg.2015.52005

[14] Asadian, F., Pourkermani, M. and Arian, M. (2007) Tectonic Geomorphology of Salt Structures in the GarmsarLasjerd Area. Geographical Research, 39, 75-84.

[15] Pourkermani, M. and Arian, M. (1997) Salt Domes of Central Iran. Journal of Humanities, 3, $29-41$.

[16] Arian, M. (2012) Salt Diapirism and Tectonics. 2nd Edition, Asar Nafis Press, Qum, 319 p.

[17] Arian, M. and Noroozpour, H. (2015) Tectonic Geomorphology of Iran's Salt Structures. Open Journal of Geology, 5, 61-72. http://dx.doi.org/10.4236/ojg.2015.52006

[18] Asadian, F. and Arian, M. (2009) Identification of Diapiric Provinces of Central Iran through Geological and Geographical Analysis. International Journal of Agriculture Environment \& Biotechnology, 2, 3443-3451.

[19] Arian, M. (2012) Clustering of Diapiric Provinces in the Central Iran Basin. Carbonates and Evaporites, 27, 9-18. http://dx.doi.org/10.1007/s13146-011-0079-9 
[20] Pourkermani, M. and Arian, M. (1998) Tectonic Geomorphology of Salt Domes in West of Zanjan Province, Iran. Geographical Research, 47, 44-53.

[21] Arian, M. and Feizi, F. (2010) The Significance of Faulting on the Surficial Spreading of Evaporitic Deposits in the Varamin-Semnan Area. Journal of Earth and Resources, 3, 1-20.

[22] Feizi, F., Arian, M. and Arian, A. (2015) Mud Diapirism on the Makran, Iran: Case Study on the Napag Mud Volcano. Open Journal of Geology, 5, 300-308. http://dx.doi.org/10.4236/ojg.2015.55027

[23] Arian, M. and Sistanipour, A. (2015) Mud Diapirism on the Gorgan. North Iran Open Journal of Geology, 5, $442-450$.

[24] Arian, M. and Khodabakhshnezhad, A. (2015) Sedimentary Environments Can Be Changed by Geotechnology (Case Study: A Morphotectonic Idea for Design of Extensive Artificial Bay on the Iranian Plateau). International Journal of Geosciences, 6, 487-496. http://dx.doi.org/10.4236/ijg.2015.65039

[25] Arian, M. (2011) Middle East Tectonics. Asar Nafis Press, Qum, 236 p.

[26] Arian, M. (2010) Applied Seismotectonics. Farazamin Press, Tehran, 304 p.

[27] Arian, M. and Maleki, R. (2008) Neotectonics. Farazamin Research Center, Tehran, 150.

[28] Pourkermani, M. and Arian, M. (1998) Seismicity of Iran. Shahid Beheshti University Press, Tehran, 212.

[29] Pourkermani, M. and Arian, M. (1997) Seismotectonics. Dez Ab Consulting Engineers Company Press, Tehran, 270.

[30] Arian, M. and Aram, Z. (2014) Relative Tectonic Activity Classification in the Kermanshah Area, Western Iran. Solid Earth, 5, 1277-1291. http://dx.doi.org/10.5194/se-5-1277-2014

[31] Mashal, M., Pour Kermani, M., Charchi, A., Almasian, M. and Arian, M. (2013) Pattern of Structural Geology Underground in Eastern of North Dezfol Embayment. Advances in Environmental Biology, 7, 260-268.

[32] Pazhoohan, M., Arian, M., Ghorashi, M. and Khosrotehrani, K. (2014) A Study of Drainage Pattern Responses to Active Tectonics in Tadvan Region, SW Iran. Geodynamics, 1, 36-41.

[33] Rahimi, N. and Arian, M. (2014) Tectonic Geomorphplogy of Kangavar-Sosangerd Region, West Iran. Advances in Environmental Biology, 8, 119-124.

[34] Arian, M. and Hashemi, A. (2008) Seismotectonic Zoning in the Zagros. Journal of Sciences, 18, 63-76.

[35] Arian, M., Ahmadnia, A., Qorashi, M. and Pourkermani, M. (2002) Structural Analysis of Mengharak Transcurrent Fault System in Zagros, Iran. Special Geo 2002 Conference Issue Geoarabia, 7, 209-210.

[36] Arian, M., Qorashi, M., Pourkermani, M. and Ahmadnia, A. (2003) Fractal Analysis of Mengharak Transcurrent Fault System in Zagros, Iran. Proceedings of the Fourth International Conference on Seismology and Earthquake Engineering, Tehran, 12-14 May 2003, 23.

[37] Baharvand, S., Pourkermani, M., Ajalloian, R., Arian, M. and Nouryazdan, A.R. (2010) Seymareh Landslide and Its Role in Environmental and Geomorphologic Changes of the Pole-Dokhtar Area. Journal of the Earth, 4, 13-24.

[38] Abdideh, M., Qorashi, M., Rangzan, K. and Arian, M. (2011) Assessment of Relative Active Tectonics Using Morphometric Analysis, Case Study of Dez River (Southwestern, Iran). Geosciences, 20, 33-46.

[39] Arian, M., Qorashi, M., Pourkermani, M. and Ahmadnia, A. (2006) The Structural Significance Kareh Bas Transcurrent Fault System in the Zagros Fold and Thrust Belt. Geosciences, 15, 126-133.

[40] Arian, M. and Noroozpour, H. (2015) Seismic Activity and Fractal Geometry of Kareh Bas Fault System in Zagros, South of Iran. Open Journal of Geology, 5, 291-299. http://dx.doi.org/10.4236/ojg.2015.55026

[41] Ehsani, J. and Arian, M. (2015) Quantitative Analysis of Relative Tectonic Activity in the Jarahi- Hendijan Basin Area, Zagros Iran. Geosciences Journal, 19, 1-15. http://dx.doi.org/10.1007/s12303-015-0016-3

[42] Omidali, M., Arian, M. and Sorbi, A. (2015) Neotectonics of Boroujerd Area, SW Iran by Index of Active Tectonics. Open Journal of Geology, 5, 309-324. http://dx.doi.org/10.4236/ojg.2015.55028

[43] Ehsani, J., Arian, M. and Ghorashi, M. (2015) Geomorphic Signatures of Active Tectonics in the Jarahi-Hendijan Drainage Basin in the South West Iran. Geosciences, 24, 211-218.

[44] Khodabakhshnezhad, A., Pourkermani, M., Arian, M., Matkan, A.A. and Charchi, A. (2015) Active Tectonics of Great Karoun River Basin. Geosciences, 24, 13-28.

[45] Maleki, Z., Arian, M., Solgi, A. and Ganjavian, M.A. (2015) Elements of Fold Style Analysis in the Karbasi Anticline, Interior Fars Region, Zagros. Geosciences, 24, 293-302.

[46] Baratpour, F., Arian, M. and Solgi, A. (2015) Geometric Analysis of Tukak and Kamarun Anticlines on Izeh Zone, Zagros. Geosciences, 24, 191-200.

[47] Fard, N.G., Sorbi, A. and Arian, M. (2015) Active Tectonics of Kangavar Area, West Iran. Open Journal of Geology, 5, 422-441.

[48] Alladin, Y., Talebian, M., Arian, M. and Ahmadi, M.M. (2015) Geotechnical Investigation and Seismic Zonation of 
Alluvial Deposits in Western Tehran. Geosciences, 24, 333-342.

[49] Taherkhani, B., Nazari, H., Pourkermani, M. and Arian, M. (2015) Geometry and Recent Kinematics of the North Qazvin Fault: Morphotectonic Approach. Geosciences, 24, 29-38.

[50] Manuchehri, H., Arian, M., Ghorashi, M., Solgi, M. and Sorbi, A. (2015) Geomorphic Signatures of Active Tectonics in the Chalus Drainage Basin in the Alborz, Iran. Geosciences, 24, 273-280.

[51] Noroozpour, H., Arian, M. and Sorbi, A. (2015) Fault Movement Potentials in the Tehran-Semnan Region (North Iran). Open Journal of Geology, 5, 281-290. http://dx.doi.org/10.4236/ojg.2015.55025

[52] Arian, M., Maleki, Z. and Noroozpour, H. (2011) Cenozoic Diastrophism and Deformational Events in the East Central Alborz. Journal of Basic and Applied Scientific Research, 1, 2394-2400.

[53] Feizi, F., Arian, A. and Rahmani, R. (2007) Seismotectonic Zoning in the Eastern Part of the Central Alborz. Journal of Sciences, 17, 151-164.

[54] Khavari, R., Arian, M. and Ghorashi, M. (2009) Neotectonics of the South Central Alborz Drainage Basin, in NW Tehran, N Iran. Journal of Applied Sciences, 9, 4115-4126. http://dx.doi.org/10.3923/jas.2009.4115.4126

[55] Arian, M. and Bagha, N. (2012) Active Tectonics of Tehran Area, Iran. Journal of Basic and Applied Scientific Research, 2, 3805-3819.

[56] Bagha, N., Arian, M., Ghorashi, M., Pourkermani, M., El Hamdouni, R. and Solgi, A. (2014) Evaluation of Relative Tectonic Activity in the Tehran Basin, Central Alborz, Northern Iran. Geomorphology, 213, 66-87. http://dx.doi.org/10.1016/j.geomorph.2013.12.041

[57] Arian, M. and Feizi, F. (2005) Application of Geomorphic Indices to the Assessment of Relative Tectonic Activity Levels in the Alborz-Central Iran Border Zone. Journal of Sciences, 15, 378-403.

[58] Arian, M., Bagha, N., Khavari, R. and Noroozpour, H. (2012) Seismic Sources and Neo-Tectonics of Tehran Area (North Iran). Indian Journal of Science and Technology, 5, 2379-2383.

[59] Moghimi, H., Arian, M. and Sorbi, A. (2015) Fault Movement Potential of Marzanabad Area, North Alborz, Iran. Open Journal of Geology, 5, 126-135. http://dx.doi.org/10.4236/ojg.2015.53012

[60] Arian, M. and Pourkermani, M. (2004) Tectonic Elements of South Flank in the East-Central Alborz Mountain. Journal of Sciences (Teacher Training University), 4, 359-368.

[61] Arian, M. and Qorashi, M. (2006) The Movement Potential Evaluation of the Major Quaternary Faults in Alborz-Central Iran Border Zone, from the East of Tehran to the East of Semnan. Journal of Geosciences, Geological Survey of Iran, 15, 184-188.

[62] Poroohan, N., Pourkermani, M. and Arian, M. (2013) An Assessment of Relationship in F-Parameter and Paleostress Fields in Heterogeneous Lithologies: Roudbar Area (Northwest of Iran). Australian Journal of Basic \& Applied Sciences, 7, 933-942.

[63] Poroohan, N., Poukermani, M. and Arian, M. (2009) An Assessment on Correlations of Seismotectonic Parameters Preceding and Following Roudbar-Manjil Earthquake (Gilan, North of Iran). Australian Journal of Basic \& Applied Sciences, 3, 2643-2652.

[64] Farrokhnia, A.R., Pirasteh, S., Pourkermani, M. and Arian, M. (2011) Geo-Information Technology for Mass Wasting Hazard Zonation: Central-West Alborz-Iran. Disaster Advances, 4, 24-33.

[65] Khavari, R., Ghorashi, M. and Arian, M. (2009) Assessment of Relative Active Tectonics, South Central Alborz (North Iran). EGU General Assembly Conference Abstracts, 11, 1137

[66] Sorbi, A., Arian, M. and Pourkermani, M. (2009) The Movement Potential Evaluation of the Major Quaternary Faults in Tehran Quadrangle. Journal of the Earth, 19, 176-182.

[67] Feizi, F. and Arian, M. (2006) The Classification of Thrust Fronts in the Alborz-Central Iran Border Zone from the East of Varamin to the East of Semnan. Journal of Sciences, 16, 75-87.

[68] Arian, M. and Feizi, F. (2005) Application of Geomorphic Indices to the Assessment of Relative Tectonic Activity Levels in the Alborz-Central Iran Border Zone. Journal of Science, 15, 378-403.

[69] Arian, M. and Pourkermani, M. (2004) Structural Significance of North Semnan and Attary Faults in Alborz-Central Iran Border Zone. Journal of Science, 14, 4551-4569.

[70] Arian, M. and Pourkermani, M. (2005) Cenozoic Diastrophism and Deformational Events in the Southern Flank of Central-East Alborz. Journal of Faculty Earth Sciences, 10, 43-51.

[71] Arian, M., Pourkermani, M., Qorashi, M. and Ghasemi, M.R. (2003) North Semnan Fault System and Its Role on Basin Division. Proceedings of the 8th Symposium of Geological Society of Iran, Shahrood, 4-6 September 2003, 11-17.

[72] Pourkermani, M. and Arian, M. (2001) Structural Geomorphology of Northeastern Kurdistan. Journal of Humanities, 7, 37-48. 
[73] Mardani, Z., Ghorashi, M. and Arian, M. (2011) Geomorphic Signatures of Active Tectonics in the Talaghanrud, Shahrud and Sefidrud Drainage Basins in Central Alborz, N Iran. Geosciences, 20, 159-166.

[74] Sorbi, A., Arian, M. and Pourkermani, M. (2011) The Application of Geomorphic Indices to the Assessment of Relative Tectonic Activity Levels in Tehran Quadrangle. Journal of the Earth, 6, 1-9.

[75] Khavari, R., Ghorashi, M., Arian, M. and Khosrotehrani, K. (2010) Geomorphic Signatures of Active Tectonics in the Karaj Drainage Basin in South Central Alborz, N Iran. Geosciences, 19, 67- 74.

[76] Mousavi, E.J. and Arian, M. (2015) Tectonic Geomorphology of Atrak River, NE Iran. Open Journal of Geology, 5, 106-114. http://dx.doi.org/10.4236/ojg.2015.53010

[77] Nouri, R., Jafari, M.R., Arian, M., Feizi, F. and Afzal, P. (2013) Correlation between Cu Mineralization and Major Faults Using Multifractal Modelling in the Tarom Area (NW Iran). Geologica Carpathica, 64, 409-416. http://dx.doi.org/10.2478/geoca-2013-0028

[78] Nouri, R., Jafari, M.R., Arian, M., Feizi, F. and Afzal, P. (2013) Prospection for Copper Mineralization with Contribution of Remote Sensing, Geochemical and Mineralographical Data in Abhar 1:100,000 Sheet, NW Iran. Archives of Mining Sciences, 58, 1071-1084. http://dx.doi.org/10.2478/amsc-2013-0074

[79] Nouri, R., Afzal, P., Arian, M., Jafari, M. and Feizi, F. (2013) Reconnaissance of Copper and Gold Mineralization Using Analytical Hierarchy Process in the Rudbar 1: 100,000 Map Sheet, Northwest Iran. Journal of Mining and Metallurgy, 49, 9-19.

[80] Arian, M. and Nouri, R. (2015) Lineament Tectonics and Mineralization in Tarom Area, North Iran. Open Journal of Geology, 5, 115-124. http://dx.doi.org/10.4236/ojg.2015.53011

[81] Feizi, F. and Arian, M. (2011) The Role of Structural Controllers in Geneses of Copper Deposits in 1:50,000 Map of Saiin Qaleh. Journal of Sciences, 21, 1-10.

[82] Arian, M., Qorashi, M. and Ahmadnia, A. (2003) Analysis of Behbahan Shear Zone. Iranian Journal of Geology, 1, 1-4.

[83] Bahiraee, S., Arian, M., Qorashi, M. and Solgi, M. (2015) The Movement Potential Evaluation of the Mosha Fault (The West of Firoozkuh to the Shahrestanak). Geosciences, 24, 123-126.

[84] Bagha, N., Ghorashi, M., Arian, M., Pourkermani, M. and Solgi, A. (2015) Neotectonic Analysis of Mosha-North Tehran Fault Zone, Based on Morphotectonic Features, Central Alborz, Northern Iran. Geosciences, 24, 41-52.

[85] Sistanipour, A. and Arian, M. (2015) Geometric Analysis of Davaran Fault System, Central Iran. Open Journal of Geology, 5, 458-469.

[86] Nazemi, M., Ghorashi, M., Ghassemi, M.R. and Arian, M. (2015) Morphotectonics Features of Alluvial Fans Associated with Active Tectonics (Shotori Mountains, East of Tabas-Central Iran). Geosciences, 24, 91-100.

[87] Alizadeh, H. and Arian, M. (2015) Rule of Structural Factors in Formation of Porphyry Copper Deposits in South Western Part of Kerman Area, Iran. Open Journal of Geology, 5, 489-498.

[88] Mosavi, E.J. and Arian, M. (2015) Neotectonics of Tabas Area, Central Iran by Index of Active Tectonics (IAT). Open Journal of Geology, 5, 209-223. http://dx.doi.org/10.4236/ojg.2015.54019

[89] Daryani, N.J., Arian, M. and Omran, N.R. (2015) Tectonics and Mineralization of Copper in the Ardestan-Kahang Area, Central Iran by Remote Sensing. Open Journal of Geology, 5, 188-196. http://dx.doi.org/10.4236/ojg.2015.54017

[90] Arian, M. and Pourkermani, M. (2001) Rivers Morphology and Active Tectonic (Reviewing the Current Status of Ghezel Ozon River in the Province of Zanjan). Proceedings of the 5th Conference of Geological Society of Iran, Tehran, 28-30 August 2001, 556.

[91] Eshghi, Z., Arian, M. and Pourkermani, M. (2012) Structural Investigation on the Lak Mining Area (Bueen Zahra) Based on Remote Sensing, Used for Its Mineralization. Journal of the Earth, 6, 145- 155.

[92] Arian, M., Toudeshki, V.H. and Noroozpour, H. (2011) Active Tectonics of Qezel Ozan River Basin, NW Iran. Journal of Applied Environmental and Biological Sciences, 1, 291-295.

[93] Alizadeh, H., Arian, M., Lotfi, M., Ghorashi, M. and Ghorbani, M. (2015) Determination of Porphyry Copper Deposit Locations Using Photo Lineament Factor in Northern Parts of the Dehaj- Sardoiyeh Belt. Geosciences, 24, $247-252$.

[94] Toudeshki, V.H., Pourkermani, M., Arian, M. and Khosrotehrani, K.H. (2011) Influence of Structures on the Ghezel Ozan River. Geosciences, 21, 55-60.

[95] Toudeshki, V.H. and Arian, M. (2011) Morphotectonic Analysis in the Ghezel Ozan River Basin, NW Iran. Journal of Geography and Geology, 3, 258-260.

[96] Arian, M. (2015) Seismotectonic-Geologic Hazards Zoning of Iran. Earth Sciences Research Journal, 19, 7-13. 
http://dx.doi.org/10.15446/esri.v19n1.40664

[97] Arian, M., Pourkermani, M., Sistanipour, A. and Noroozpour, H. (2011) Kinematic Significance of Fold- and Fault-Related Fracture Systems in the Rafsanjan's Northeast Highlands (Central Iran). Journal of Basic and Applied Scientific Research, 1, 3398-3406.

[98] Arian, M., Pourkermani, M., Sistanipour, A. and Noroozpour, H. (2011) Seismicity and Fault Segmentation of Bafq-Baghin Fault System (Central Iran). Journal of Applied Environmental and Biological Sciences, 1, 382-396.

[99] Mosavi, E.J., Arian, M., Ghorashi, M. and Nazemi, M. (2012) Measurements of Geomorphic Indices in Tabas Area. Journal of the Earth, 7, 213-225.

[100] Arian, M. (2010) Earthquake-Fault Hazard Investigations in the Kerman Quadrangle. Journal of Sciences, 19, $176-182$.

[101] Brönnimann, P., Zaninetti, L., Bozorgnia, F., Dashti, G.R. and Moshtaghian, A. (1971) Lithostratigraphy and Foraminifera of the Upper Triassic Naiband Formation, Iran. Revue de Micropaléontologie, 14, 7-16.

[102] Bull, W.B. (2007) Tectonic Geomorphology of Mountains: A New Approach to Paleoseismology. Blackwell, Malden. http://dx.doi.org/10.1002/9780470692318

[103] Hack, J.T. (1973) Stream-Profiles Analysis and Stream-Gradient Index. Journal of Research of the U S Geological Survey, 1, 421-429.

[104] Cox, R.T. (1994) Analysis of Drainage Basin Symmetry as a Rapid Technique to Identify Areas of Possible Quaternary Tilt Block Tectonics: An Example from the Mississippi Embayment. Geological Society American Bulletin, 106, 571-581. http://dx.doi.org/10.1130/0016-7606(1994)106<0571:AODBSA>2.3.CO;2

[105] Arian, M. (2010) Earthquake-Fault Hazard Investigations in the Kerman Quadrangle. Journal of Sciences, 19, $176-182$.

[106] Farrokhnia, A.R., Pirasteh, S., Pradhan, B., Pourkermani, M. and Arian, M. (2011) A Recent Scenario of Mass Wasting and Its Impact on the Transportation in Alborz Mountains, Iran Using Geo-Information Technology. Arabian Journal of Geosciences, 4, 1337-1349. http://dx.doi.org/10.1007/s12517-010-0238-7 